Niniejsza publikacja jest dostępna na licencji Creative Commons. Uznanie autorstwa-Użycie niekomercyjne-Bez utworów zależnych 3.0 Polska. Pewne prawa zastrzė̇one na rzecz autora. Zezwala się na wykorzystanie publikacji zgodnie z licencja - pod warunkiem zachowania niniejszej informacji licencyjnej oraz wskazania autora jako właściciela praw do tekstu. Treść licencji jest dostępna na stronie: http://creativecommons.org/licenses/by-nc-nd/3.0/pl/

Lingwistyka Stosowana 19: 4/2016, 47-59

\author{
Bogumil GASEK
}

Uniwersytet Wrocławski

\title{
Wiedza akcentologiczna w nauczaniu języka rosyjskiego na studiach rusycystycznych
}

\begin{abstract}
:
Knowledge of accentology in teaching Russian as a foreign language

The present paper discusses the usage of theoretical knowledge of accentology (works by A. Zalizniak) and materials from Polish coursebooks on Russian language accentology (works by M. Olechnowicz and by D. Dziewanowska) in order to propose a model for self-acquisition and reinforcement by which students can determine the right word stress in Russian words. The model presented by author implies active usage of theoretical knowledge while watching Russian speaking TV as well as in communication with native speakers of Russian language.
\end{abstract}

\section{Wstęp}

Opanowanie poprawnej akcentuacji rosyjskiej można zaliczyć do największych trudności w procesie przyswajania języka rosyjskiego przez Polaków. Wynika to ze specyfiki rosyjskiego systemu akcentuacyjnego (akcent swobodny oraz ruchomy) przy odmienności analogicznego systemu w języku polskim (akcent w zdecydowanej większości form nieswobodny, paroksytoniczny (na przedostatnią sylabę)). Konieczność przełamania tejże trudności, a więc nabycia umiejętności poprawnego akcentowania wyrazów, wynika $\mathrm{z}$ kolei $\mathrm{z}$ dystynktywnej funkcji rosyjskiego akcentu (ведение - ведение), funkcji różnicowania form gramatycznych (воды - воды), organizacji rytmicznej słowa (w odróżnieniu od polszczyzny w j. rosyjskim sylaby nieakcentowane ulegają znacznej redukcji ilościowej i jakościowej, a więc ewentualny błąd akcentuacyjny przy standardowej redukcji może zaburzać komunikację). Poza tym poprawna akcentuacja (w przypadku języka nienatywnego tak należy rozumieć właściwych wybór przycisku przynajmniej w większości słowoform) stanowi dla rusycysty atrybut jego profesji. Staje się on jeszcze ważniejszy, gdy jego praca zawodowa bezpośrednio wiąże się $\mathrm{z}$ działalnością mowną w języku rosyjskim (wykładowca akademicki, nauczyciel, thumacz ustny).

Celem niniejszego artykułu jest uzupełnienie stosowanych w środowisku rusycystycznym i opisanych teoretycznie metod nauczania akcentuacji rosyjskiej o nowy schemat przyswajania i utrwalania poprawnej akcentuacji przez studenta rusycystyki.

Jak podaje K.S. Gorbaczewicz, jeszcze w 1927 roku D.N. Uszakow na pytanie, 
czy w języku rosyjskim istnieją normy akcentuacyjne, miał odpowiedzieć przecząco: „Нет, установленных правил ударения нет” (К.С. Горбачевич 1978: 86). Jednak wraz z postępującymi badaniami akcentologicznymi takich uczonych, jak m.in. R.I. Awaniesow ( Р.И. Аванесов 1955; Р.И. Аванесов 1968), А.A. Zalizniak (А.А. Зализняк 1967; А.А. Зализняк 1985), A.W. Supieranskaja (А.В. Суперанская 1968), W.A. Riedkin (B.A. Редькин 1971), W.W. Kolesow (B.В. Колесов 1972), T.G. Chazagierow (Т.Г. Хазагеров 1973), M. Olechnowicz (M. Olechnowicz 1974a; M. Olechnowicz 1974b; M. Olechnowicz 1977), K.S. Gorbaczewicz (К.С. Горбачевич 1978), W.L. Woroncowa (В.Л. Воронцова 1979) i in. stało się jasne, że system akcentuacyjny języka rosyjskiego można w zasadzie sprowadzić do określonej liczby paradygmatów, reguł oraz szeregu wyjątków i oboczności (istnienia równoprawnych i nierównoprawnych wariantów akcentuacyjnych), jako wyniku naturalnych procesów rozwoju języka. Szczegółowe informacje o paradygmatach akcentuacyjnych podaje przede wszystkim Stownik gramatyczny A.A. Zalizniaka (A.A. Зализняк 2009), natomiast pomocne dla dydaktyków mogą być reguły (w liczbie 260), które załączyła do swojego słownika I.L. Riezniczienko (И.Л. Резниченко 2015). Niewątpliwie najbardziej wiarygodnym źródłem wiedzy o poprawnej akcentuacji konkretnej słowoformy są duże słowniki ortofoniczne oraz słowniki akcentuacji. Zaliczyłbym do nich takie pozycje, jak SA, SIw, SR, SK, SJe, SZ, SAg (na końcu artykułu załączam rozwinięcia skrótów).

Poza tym w tychże słownikach znajdziemy mniej lub bardziej obszernie opracowane zestawy reguł akcentuacyjnych oraz artykuły teoretyczne (zob. np. Р.И. Аванесов 1989; М.Л. Каленчук/ Л.Л. Касаткин/ Р.Ф. Касаткина 2012; Н.А. Еськова 2014).

Dość różnorodnie przedstawiają się prace glottodydaktyczne z zakresu akcentuacji. Na gruncie polskim można do nich zaliczyć badania i podręczniki W. Gałeckiego (W. Gałecki 1965), M. Olechnowicza (M. Olechnowicz 1974; M. Olechnowicz 1976;), J. Henzla (J. Henzel 1978), D. Dziewanowskiej (D. Dziewanowska 2005). Na szczególną uwagę zasługuje metoda reproduktywno-kreatywna autorstwa J. Henzla, która ,zasadza się na stopniowym przechodzeniu od najprostszych ćwiczeń z wymowy i intonacji oraz od dosłownej reprodukcji tekstu do wszechstronnego opanowania języka rosyjskiego, do twórczości językowej” (J. Henzel 1978: 6) oraz „koncepcja aspektowo-kompleksowego nauczania akcentuacji" (D. Dziewanowska 2005: 92), której praktycznym przejawem są podręczniki z serii Akcent rosyjski: ćwiczenia praktyczne (D. Dziewanowska 2000a, D. Dziewanowska 2000b, D. Dziewanowska 2000c), a teoretyczne aspekty zostały omówione w monografii tejże autorki (D. Dziewanowska 2005). Należy odnotować również kilka podręczników akcentuacyjnych wydanych w ZSRR i Rosji - są to m.in.: (Н.A. Федянина 1976), ( Ю.Г. Лебедева 1986), ( М.Н. Шутова 2013).

Wspomniane podręczniki D. Dziewanowskiej są wykorzystywane w różnych ośrodkach akademickich w Polsce na zajęciach praktycznych z języka rosyjskiego (w tym w Instytucie Filologii Słowiańskiej UWr.). Pewnym ich mankamentem jest zaliczenie do modelu карандаш (akcent na końcówce we wszystkich przypadkach zależ- 
nych) wyrazu гроб (D. Dziewanowska 2000b: 63), który wszystkie duże słowniki ortofoniczne klasyfikują jako rzeczownik z akcentem na temacie w liczbie pojedynczej i końcówce w liczbie mnogiej (гроб, гроба, ale w liczbie mnogiej гробы, гробōв). Ponadto autorka do schematu akcent na temacie w liczbie pojedynczej i na końcówce w liczbie mnogiej odniosła rzeczownik мост (D. Dziewanowska 2000b: 72), chociaż w danym wyrazie część słowników ortofonicznych dopuszcza dwojaką akcentuację w przypadkach zależnych w liczbie pojedynczej (wg SJe i SR poprawne jest zarówno моста, jak і моста, ale јuż SK wskazuje моста, uznając моста za formę dopuszczalną (starszą normę), natomiast SIw i SZ odnotowują wyłącznie моста). W związku z tym użytkownik podręcznika powinien zostać uprzedzony o danej rozbieżności i ewentualnie o tendencji, jaką, sądząc po informacji podanej w trzech ostatnich wymienionych słownikach, jest przejście tego wyrazu do schematu c wg klasyfikacji Zalizniaka.

Pomijając dane zastrzeżenia, można zgodzić się ze stwierdzeniami autorki, że dana metoda pozwala na znaczące zniwelowanie błędów akcentuacyjnych. Staranne i przejrzyste opracowanie schematów akcentuacyjnych poszczególnych części mowy, przemyślana i wielka liczba ćwiczeń utrwalających, ilustracje z użyciem frazeologizmów, formuł etykiety językowej i przysłów, decydują o jej skuteczności. Bezpośrednio potwierdzają to również wyniki precyzyjnie omówionego eksperymentu dydaktycznego, co autorka podsumowuje w następujący sposób: „Eksperyment dydaktyczny wykazał skuteczność koncepcji aspektowo-kompleksowego nauczania akcentuacji rosyjskiej na studiach rusycystycznych opartego na komplementarnym zastosowaniu elementów podejścia kognitywnego i komunikacyjnego. Można przypuszczać, że koncepcja ta mogłaby być przydatna również w nauczaniu akcentuacji w szkole i na lektoratach w uczelniach wyższych" (D. Dziewanowska 2005: 250). Nie oznacza to, jednak, że nauczanie akcentuacji rosyjskiej w warunkach studiów filologicznych powinno ograniczać się do odbycia przez studenta dwuletniego kursu fonetycznego (tak się dzieje na wrocławskiej rusycystyce, natomiast koncepcja D. Dziewanowskiej zakłada stopniową realizację materiału w ciągu pięciu lat studiów rusycystycznych (D. Dziewanowska 2005: 127)). Opanowanie skomplikowanego systemu akcentuacji wymaga intensywnej, ciągłej, wieloletniej i wieloaspektowej pracy na różnych zajęciach i samodzielnie poza uczelnią. Poniżej przedstawiam metodę utrwalania, pogłębiania i, co ważne, samodzielnego rozszerzania wiedzy i umiejętności w zakresie akcentuacji rosyjskiej. Metoda ta jest wynikiem wieloletnich obserwacji dokonywanych przez autora na zajęciach z zakresu Gramatyki Współczesnego Języka Rosyjskiego (fonetyki/ fonologii) na pierwszym roku studiów w cyklu licencjackim oraz różnych aspektów praktyki przekładu (przekład pisemny, ustny, audiowizualny) zajęć w cyklu magisterskim prowadzonych w Instytucie Filologii Słowiańskiej Uniwersytetu Wrocławskiego, a także lektury wzmiankowanych słowników ortofonicznych, wymienianych prac z zakresu akcentologii, kultury języka i glottodydaktyki. 


\section{Metoda samodzielnego przyswajania i utrwalania poprawnej akcentuacji}

Schemat nabywania i poszerzania umiejętności używania poprawnych form akcentuacyjnych zakłada współistnienie dwóch zasad - zaznajamianie się z regułami akcentuacyjnymi i paradygmatami oraz utrwalanie i samodzielne przyswajanie akcentu $\mathrm{w}$ poszczególnych słowoformach w trakcie oglądania i słuchania rosyjskich programów telewizyjnych, filmów, seriali, wykładów, wystąpień telewizyjnych, piosenek, rozmów z wykształconymi rodzimymi użytkownikami języka rosyjskiego itp. Student na podstawie nabywanej wiedzy o akcentuacji rosyjskiej w trakcie kontaktu z żywą mówioną ruszczyzną sam wyciąga wnioski odnośnie do poprawnego miejsca przycisku w określonych formach. Mechanizm ten działa w następujący sposób: znam regułę ogólną - słyszę konkretną słowoformę - wiem, jak wygląda cały paradygmat (1) albo jego część (2).

Przeanalizujmy konkretny przykład: (1) słyszę formę они подбросили. Z ogólnej zasady akcentuacji czasowników wnioskuję, że akcent pada na temat we wszystkich formach czasownikowych oprócz form trybu dokonanego z prefiksem вы-. Stąd też po usłyszeniu jednej jedynej słowoformy i przy założeniu, że jest ona poprawna (o tym dalej), zapamiętując ją, mogę dalej poprawnie akcentować dziesiątki innych form pochodnych - сброшу, они подбросят, забросила i tak dalej. Dokładnie ten sam algorytm może być zastosowany w przypadku usłyszenia po raz pierwszy także innych form tego czasownika (oprócz wyżej wymienionego wyjątku): bezokolicznika, dowolnej formy czasu przeszłego, pierwszej osoby czasu teraźniejszego. W przypadku pozostałych form osobowych czasu teraźniejszego - usłyszenie ich po raz pierwszy pozwala jedynie ograniczyć możliwość przynależności słowa do konkretnego paradygmatu akcentuacyjnego. Zasłyszana forma красит daje pewność, że w drugiej i trzeciej osobie liczby pojedynczej i mnogiej akcent nie pada na końcówkę, ale nie pozwala na stuprocentowe określenie poprawnego miejsca akcentuacji w bezokoliczniku, a co za tym idzie w formach czasu przeszłego (teoretycznie taki czasownik mógłby należeć do paradygmatu c zgodnie $\mathrm{z}$ klasyfikacją A.A. Zalizniaka (A.A. Зализняк 2010: 80), a więc modelu ходить, хожу, ходишь). W ten sposób dochodzimy do punktu (2) praktycznego zastosowania omawianych zasad: forma wyjściowa pozwala wskazać poprawą akcentuację niektórych słowoform i/lub wykluczyć określone miejsce przycisku w innych.

W przypadku rosyjskich rzeczowników rodzaju męskiego kluczowe znaczenie w takiej strategii ma forma dopełniacza liczby pojedynczej. Jeśli usłyszę formę dopełniaczową z akcentem na dodanej końcówce, od razu wiem, jak wygląda cały paradygmat, co skrzętnie odnotowuję w pamięci bez potrzeby uczenia się oddzielnych kilkunastu form. Jeśli poprawna jest forma мечa, to akcent pada na końcówkę we wszystkich pozostałych przypadkach zależnych. Akcent na temacie w dopełniaczu wskazuje, że w pozostałych przypadkach zależnych w liczbie pojedynczej utrzyma się on na tej samej sylabie, np. dopełniaczowa forma дара (od дар) implikuje formy дару, даром, (о) даре. Do stuprocentowego określenia całego paradygmatu potrzebujemy jeszcze którejś z form liczby mnogiej. Idąc dalej tym tokiem rozumowania: $\mathrm{z}$ dop. брата i $m$. l.m. братья wynika, m.in. akcent w formach братом, ale i братьях. W przypadku 
słów, liczących więcej niż dwie sylaby niekiedy jedna słowoforma wystarcza do określenia całego paradygmatu, np. jeśli akcent nie pada w którejkolwiek usłyszanej co najmniej trzysylabowej słowoformie na ostatnią sylabę - akcent należy stawiać na temat we wszystkich słowoformach, np. usłyszałem в санатории, wiem, że poprawnie jest санаторий; санаториев; санаториях.

Na podobnej zasadzie można wykorzystywać w praktyce wiedzę o pozostałych paradygmatach akcentuacyjnych, np. w przypadku przymiotników minimalizacja błędów akcentuacyjnych następuje, gdy student zapamięta najpopularniejsze przymiotniki na akcentowane -ŏ̆. Pomocne będą w tym także relacje semantyczno-akcentuacyjne -duża grupa takich przymiotników oznacza negatywne cechy / ułomności psychologiczne i fizyczne, np. глухой; хромой; худой (А.А. Зализняк 1967: 543). Wychwytywanie kolejnych (nawet jeśli założyć, że w trakcie zajęć ta grupa przymiotników zostanie przedstawiona w sposób wyczerpujący, pozostaje problem utrwalenia informacji akcentuacyjnej) przykładów takich przymiotników jest stosunkowo proste: wystarczy, że student usłyszy którąkolwiek formę gramatyczną (np. слепых), a będzie wiedział, że ma do czynienia z przymiotnikiem na -ŏ̆ i umiał poprawnie zaakcentować wszystkie formy gramatyczne (слепая, слепого, слепыми itp.).

Praktyczne zastosowanie danej metody widzę dwuetapowo: zadaniem wykładowcy jest poprzez wykonywanie odpowiednich ćwiczeń, korzystanie z podręczników, zalecenie samodzielnej lektury zaznajomienie studenta w ciągu dwóch-trzech semestrów nauki języka kierunkowego z paradygmatami akcentuacyjnymi języka rosyjskiego oraz wyrobienie nawyku stosowania wyżej opisanej procedury. Student następnie prowadzi samodzielne działania (w przypadku późniejszego zawodowego wykorzystania języka rosyjskiego ten proces nigdy nie ustaje, co należy uczącym się uświadamiać!) w trakcie codziennego kontaktu z żywą, mówioną ruszczyzną (w warunkach polskich częściej za pomocą Internetu lub telewizji i radia), wykorzystując algorytm uczenia się i utrwalania poprawnej akcentuacji.

Prezentowana metoda ma na celu radykalne zmniejszenie liczby błędów akcentuacyjnych (w przypadku niektórych form można je wyeliminować, w innych zredukować, wreszcie ważne jest, żeby popełniane błędy miały znaczenie marginalne i zdarzały się raczej w formach, które również dla rodzimych użytkowników ruszczyzny mogą być problematyczne: niektóre nazwy własne, terminy, leksyka rzadka i archaiczna). Nie uważam za możliwe (jeśli wykluczyć sytuację wieloletniego, ciągłego funkcjonowania w naturalnym środowisku językowym) opanowania akcentuacji na poziomie wykształconego rodzimego użytkownika języka rosyjskiego, natomiast powyższa metoda pozwala na osiągnięcie znacznie lepszych rezultatów, niż w przypadku dwóch innych skrajnych metod: a) niewykorzystywanie teoretycznych zasad w nadziei na stopniowe przyswojenie akcentu rosyjskiego drogą ,osłuchania się” z językiem (moim zdaniem trudno przyswoić sobie poza środowiskiem naturalnym i w wieku dorosłym rosyjską akcentuację nawet w najbardziej rozpowszechnionych słowoformach. Bez elementarnej wiedzy teoretycznej zróżnicowanie form рука, рукй, рукё; руки, руками, ale две рукй zazwyczaj pozostaje dla uczącego się zagadką. Próba powtarzania zasłyszanych form, liczenie na to, że zapoznanie się z ,melodią języka" jest równoznaczne $\mathrm{z}$ poprawnym umieszczaniem przycisku wyrazowych 
bywa złudne.

Częściej taka metoda skutkuje przypadkową akcentuacją i to poprawnym, to błędnym akcentowaniem tych samych, opanowanych już pamięciowo wyrazów. b) bezrefleksyjne zapamiętywanie reguł, ,treningowe" czytanie tekstów z zaznaczonymi akcentami, ale bez umiejętności wykorzystania w realnej sytuacji mownej i bez umiejętności dalszego przyswajania sobie nowych form (zostaje zapamiętany nowy wyraz z poprawną akcentuacją, ale bez automatycznego zaszeregowania go do określonego paradygmatu akcentuacyjnego, zastosowania określonej reguły i tak dalej).

Przy wdrażaniu omawianego schematu pomocne będzie systematyczne sygnalizowanie na zajęciach istnienia prawidłowości akcentuacyjnych, zwłaszcza bezwyjątkowych. Do takich zaliczyłbym niektóre sufiksy i prefiksy, mające w języku rosyjskim w określonym użyciu i funkcji stały akcent: wspomniany już prefiks вы- w formach aspektu dokonanego czasowników i imiesłowów, nр. выдумать; вышел; выбранный; выцветший; -ат- w przymiotnikach, np. ушастый; головастый; akcent padający na sylabę poprzedzającą sufiks -ива-, -ыва-, w formach trybu niedokonanego czasowników (разговаривать) itd.

Skuteczność postulowanej metody wymaga jednakże dodatkowego zwrócenia uwagi w procesie dydaktycznym na kilka wyjątków i szczególnych grup leksykalnych. Omówię je w kolejnych punktach.

\section{Odtwarzalne wielowyrazowce}

Jest rzeczą zrozumiałą, że w niektórych odtwarzalnych wielowyrazowcach idiomach, frazeologizmach, przysłowiach innych formach skostniałych) swoistemu zakonserwowaniu uległy archaiczne i przestarzałe formy leksykalne (ни зги не видно), gramatyczne (притча во языцех), сzy akcentuacyjne właśnie. Zwrócenie bacznej uwagi na tę grupę różnego rodzaju odtwarzalnych wielowyrazowców (z praktycznego punktu widzenia nie ma tu znaczenia, czy są to frazeologizmy, przysłowia czy inne typy frazemów, istotna jest ich ponadwyrazowa struktura i fakt odtwarzalności w określonych sytuacjach mownych). Zauważmy, że odtwarzalne wielowyrazowce pełnią kluczową funkcję w tworzeniu tekstów / wypowiedzi i przy recepcji takowych, a więc każda próba dodatkowego poszerzenia zasobu danych jednostek jest na zajęciach z języka kierunkowego pożądana. Stosowanie omawianej i postulowanej przez nas metody przyswajania akcentuacji może ulegać zaburzeniom, gdy student napotka wielowyrazowiec zawierający komponent o innym (poprawnym) miejscu akcentuacji, niż w tymże słowie, ale tworzący luźny związek wyrazowy. Innymi słowy usłyszenie przez studenta w wypowiedzi native speakera formy $\mathrm{z}$ innym miejscem przycisku, niż wcześniej przyswojony powoduje zamęt myślowy i prowadzi do dezorientacji oraz rozpadu pieczołowicie konstruowanego na indywidualne potrzeby paradygmatu akcentuacyjnego. Porównajmy: spotykam się z formą шyтa - bez problemu tworzę formę wyjściową - шyт oraz poprawnie umiejscawiam przycisk w przypadkach zależnych (np. с шутом), w liczbie mnogiej шуты्, о шутаx itd. Całokształt akcentuacyjny niweczy zasłyszana forma с какого шута? Powstają zasadne pytania: czy jest ona poprawna? Jeśli tak, to czy uprzednio zapamiętany paradygmat akcentuacyjny jest poprawny, może jego zachowana w pamięci konstrukcja to rezultat zapamiętania 
błędnej formy wyjściowej? Wszystkie te problemy można częściowo zniwelować, wprowadzając na zajęciach najbardziej rozpowszechnione odtwarzalne wielowyrazowce charakteryzujące się osobliwościami akcentuacyjnymi. Takie działanie uświadamia istnienie samego zjawiska i pozwala rozdzielić w naszej świadomości przypadki stosowania oddzielnych słów i niektórych (specyficznych z punktu widzenia akcentuacji) wielowyrazowców. Pamiętajmy też, że poprawna akcentuacja w takich jednostkach języka jest nie mniej istotna, niż w pojedynczych słowach i luźnych związkach wyrazowych.

Poniżej podaję propozycję kilkunastu jednostek, wskazując w nawiasie standardową formę akcentuacyjną: всем сестрам по сергам (standard. сёстрам); не было ни гроша, да вдруг алтын (w zasadzie гроша, chociaż w odniesieniu do Austrii i Polski - гроша, zob. np. SJe); назвался груздем - полезай в кузов (standard. груздём); красна девица; девица-красавица (standard. девицца); бить (драть / лупить) как

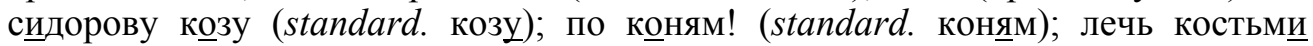
(standard. костями); выписывать кренделя; выделывать кренделя (w liczbie mnogiej dopuszczalne są formy крендели і кренделя, ale we frazeologizmach wyłącznie кренделя); многая лета (standard. лета); утро вечера мудренеe (standard. мудрёнее); иди к свиньям (standard. свиньям); следа не осталось (standard. следа i следа (zob. SK), ale we frazeologizmie tylko следа); волею судеб (standard. судеб); какими судьбами (standard. судьбами); царствие теней (standard. теней (forma теней w luźnych związkach wyrazowych jest klasyfikowana jako przestarzała (zob. SIw, SR) lub zarezerwowana dla tekstów poetyckich (zob. SJe)); ни черта (standard. чёрта); хоть шаром покати (standard. шаром); какого шута (standard. шута).

\section{Osobliwości gramatyczno-akcentuacyjne}

Ważną regułą gramatyczną języka rosyjskiego jest łączliwość liczebników 2, 3, 4 z rzeczownikami w formie dopełniacza liczby pojedynczej, a więc np. 2 жены (liczba mnoga жёны); 24 автобуса (mianownik liczby mnogiej: автобусы). W kontekście danej reguły konieczne jest zwrócenie uwagi studenta na istnienie kilku archaicznych form akcentuacyjnych w połączeniu z liczebnikami 2, 3, 4. Zaliczyłbym do nich 2, 3, 4 часа (również w połączeniu z kilkoma innymi z formami liczebnikowymi полтора, четверть часа, chociaż w dopełniaczu liczby pojedynczej jest часа; 2, 3, 4 ряда (w dopełniaczu liczby pojedynczej ряда) oraz 2, 3, 4 шага (w dopełniaczu liczby pojedynczej шага). Tu jednak należy skłonić studentów do sięgnięcia po słownik ortofoniczny - fakt odnotowywania również połączeń typu два шага jako niezalecanych (SJe i SK) świadczy o rozpowszechnieniu tego zjawiska, z czego można wysnuć dwa wnioski: napotkanie $\mathrm{w}$ mowie formy $\mathrm{z}$ akcentem na przedostania sylabę nie powinno wywołać dezorientacji, natomiast powszechność tego zjawiska świadczy zapewne o pewnej tendencji, co oznacza, że z czasem możliwa jest zmiana normy. Nieco inaczej przestawia się kwestia rzeczownika wap. Ze względu na większy stopień komplikacji i niejednoznaczność akcentuacyjną połączeń два, три, четыре шара ten przykład doskonale mógłby posłużyć jako zadanie do samodzielnego ustalenia poprawnych form z wykorzystaniem słowników ortofo-nicznych. Niewątpliwe dojście do pewnej prawidłowości drogą własnych poszukiwań pozostawi w pamięci studenta głębszy ślad, 
niż automatyczne powtarzanie podawanej (a więc przygotowanej na potrzeby zajęć) formy.

\section{Przesunięcie akcentu na przyimek}

W języku rosyjskim w niektórych połączeniach przyimka z rzeczownikiem ma miejsce przesunięcie akcentu na przyimek, nр. ходить по полю. W nauczaniu poprawnej akcentuacji należy wykorzystywać wiedzę o znaczeniach niesionych przez określone formy akcentuacyjne, np. akcent mogą przejąć: przyimek sa w znaczeniu 'w ciągu' (w połączeniu z jednostkami czasu) сделать за год; за день; за ночь; за зиму (zob. А.А. Зализняк 2010: 72), w znaczeniu 'po drugiej stronie, z tyłu', np. уйти за реку; за гору; заложить что-л. за щеку; за ухо; заложить руки за спину; за голову (zob. А.А. Зализняк 2010: 72) itd.

Podobnie jak w punkcie 1. sprawą wielkiej wagi są różnego rodzaju wielowyrazowce, zawierające $\mathrm{w}$ swojej strukturze formy $\mathrm{z}$ akcentem padającym na przyimek

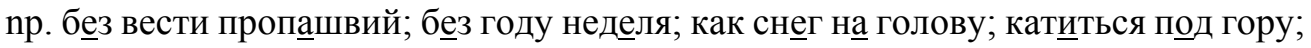
пойтй по миру; положа руку на сердце і inne.

\section{Litera ë}

Niemało miejsca na zajęciach praktycznych należy poświęcić literze ë - z zasady akcentowanej (wyjątek to niektóre złożenia, jak np. четырёхкомнатный, gdzie należy mówić jedynie o akcencie pobocznym, a więc słabszym, ale jednak pozwalającym na zachowanie jakości dźwięku [r'o]), ale - znowuż - z zasady nieoznaczanej w tekście graficznie. Tutaj normą można uczynić stopniowe wprowadzanie na zajęciach i do ćwiczeń słów z ë o największej frekwencyjności w języku. Pomocne w przygotowywaniu materiałów i zestawów ćwiczeń mogą być listy proponowane w niektórych podręcznikach np. ( Г.Ю. Богданович/ Э.М. Сапожникова 2000: 16), źródła internetowe czy oddzielny słownik wyrazów z literą ë opublikowany w pracy Je.W. Pcziełowa i W.T. Czumakowa (Е.В. Пчелов/ В.Т. Чумаков 2000), choć oczywiście samo podawanie list do zapamiętywania z metodologicznego punktu widzenia mija się z celem. Słowa o największej częstotliwości winny trafiać do ćwiczeń.

\section{Nazwy własne}

Nazwy własne stanowią ważną i obszerną kategorię leksykalną, której zasoby muszą być stale poszerzane przez studenta rusycystyki. Zasadniczym nawykiem akcentuacyjnym, który adept zawodu musi nabyć, jest przestrzeganie akcentu nieruchomego w przypadkach zależnych w większości toponimów, imion (wyjątek Пётр - Петраa; Лев - Льва), imion odojcowskich i nazwisk. Stąd też konieczne jest zestawianie form w Kraków - w Krakowie і Кра̨ков - в Краккове. Podobne ćwiczenia proponował w swoim podręczniku już M. Olechnowicz (M. Olechnowicz 1974c: 122).

Nazwiska funkcjonujące w kulturze rosyjskiej podzieliłbym na dwie kategorie. Pierwsza to najpopularniejsze nazwiska, w których błędy akcentuacyjne są dla filologa nie do przyjęcia. Tu pomocne będzie stopniowe wprowadzanie takich form, w oparciu np. o listę sporządzoną przez W.P. Bierkowa w pracy Русские имена, 
отчества и фамилии. Правила Употребления (В.П. Берков 2005: 64-69). Na marginesie można dodać, że ta niewielka objętościowo książeczka wybitnego rosyjskiego językoznawcy powinna być lekturą obowiązkową dla każdego studenta rusycystyki. Druga kategoria to różne pod względem struktury nazwiska znanych osób (polityków, dziennikarzy, aktorów, pisarzy, muzyków, sportowców itp.). Student musi sobie wyrobić nawyk przyswajania połączenia forma fonetyczna (akcentuacja) i podstawowa informacja o postaci, sprowadzająca się w praktyce do odpowiedzi na dwa trywialne pytania: z czego dana osoba jest w Rosji znana, i z czym jej nazwisko Rosjanom się kojarzy. Doprowadzając do automatyzmu zapamiętywanie form używanych w autentycznej komunikacji medialnej, student jednocześnie uczy się używania ich nie tylko we właściwej postaci fonetycznej (w tym i akcentuacyjnej), ale i w najpopularniejszych wariantach użycia w naturalnym środowisku językowym (por. możliwe Аллла Борисовна (о piosenkarce Пугачёвой), Дима Билан itp. Istotne jest też różnicowanie form typu Абрамович (np. Роман Аркадьевич - nazwisko) і Абрамович (imię odojcowskie, np. Борйс Абрамович Березовский).

Proces przyswajania poprawnych form akcentuacyjnych ułatwia znajomość nie tylko szczegółowych zasad, ale również bardziej ogólnych prawidłowości i tendencji w rozwoju języka. Dlatego też warto zwrócić uwagę studentów na zauważalną w ostatnich dwudziestu latach skłonność do dyferencjacji akcentuacyjnej imion w zależności od tego, czy ich użytkownikami są Rosjanie, czy osoby spoza rosyjskiego obszaru językowego. O Rosjaninie powiemy Станислав, ale o Polaku raczej Станислав (nр. Станислав Ежи Лец). Rosjanka to Вероника, ale znana w Rosji meksykańska aktorka to јuż Вероника Касстро, jedno z popularnych rosyjskich imion to Вㅡктор, ale francuski pisarz funkcjonuje jako Виктор Гюгㅇ. W rosyjskich środkach masowego przekazu używa się form Бронислав Коморовски, Адам Малыш, przy naturalnym w rosyjskim środowisku językowym - Бронислав, Адам.

Uczący się powinni mieć również świadomość istnienia dubletów akcentua-cyjnych wśród nazw miast i państw obcych. W wielu przypadkach rozbieżności akcentuacyjne wynikają z istnienia dwóch przeciwstawnych modeli adaptacji - zachowania miejsca akcentu języka źródłowego i tradycji akcentuacyjnej (często wg modelu języka pośredniczącego przy zapożyczeniu). Zakres danej problematyki wychodzi poza ramy niniejszego artykułu, dlatego też ograniczę się do podania jednego charakterystycznego przykładu: normatywne, tradycyjnie funkcjonujące w ruszczyźnie Вашингтон (stolica USA) i funkcjonujące w uzusie Вашшингтон (tę ostatnią formę odnotowują niektóre słowniki; za dopuszczalną uznaje ją np. A. Supieranskaja w słowniku dołączonym do monografii Ударение в собственных именах в современном русском языке (В.А. Суперанская 2011: 255)). Znajomość ogólnych prawidłowości w tym przypadku uchroni uczącego się przed rozterkami interpretacyjnymi, które mogłyby działać demotywująco.

\section{Warianty akcentuacyjne}

$\mathrm{W}$ procesie historycznego rozwoju w języku rosyjskim zachodzą stopniowe zmiany niektórych norm akcentuacyjnych, pewne słowa zmieniają przynależność do określo- 
nego paradygmatu akcentuacyjnego, co z oczywistych względów jest procesem stopniowym. $Z$ tego względu naturalna prawidłowość to utrzymywanie się przez pewien czas dwóch różnych wariantów akcentuacyjnych, zwykle wskazywanych w słownikach ortofonicznych jako norma młodsza i starsza. Takie równorzędne formy akcentuacyjne (nр. одновременно і одновременно) powinny znaleźć się w programie nauczania, choćby z tego względu, że funkcjonowanie form fakultatywnych wprowadza dezorientację przy praktyce stosowania metody prezentowanej i proponowanej $\mathrm{w}$ niniejszym artykule. W praktyce jednak należy dążyć do tego, aby student konsekwentnie używał jednego, wybranego wariantu, mając jednak świadomość istnienia formy $\mathrm{z}$ innym akcentem.

Od takich równoprawnych form (dubletów) należy odróżnić warianty stylistyczne i nierównoprawne. Ten ostatni przypadek również wymaga uwagi. Na profesjonalnym poziomie nauczania języka rosyjskiego konieczne jest zaznajamianie się z powszechnie funkcjonującymi naruszeniami normy, gdyż świadomość rozbieżności akcentuacyjnych w konkretnych słowoformach uchroni formujący się w pamięci schemat poprawnych form akcentuacyjnych przed zaburzeniami. Napotkana w żywej ruszczyźnie mówionej forma оптовый winna skłonić studenta, który uprzednio przyswoił sobie normatywną formę оптовый, do sięgnięcia po słownik ortofoniczny.

\section{8. Źródla}

Wykorzystanie omawianego schematu wymaga odwołania się do kilku zasad. Przede wszystkim zasada wiarygodności źródeł - metodę samodzielnego zapamiętywania i kwalifikowania w pamięci określonych form akcentuacyjnych należy stosować przy wykorzystaniu takich źródeł, jak rosyjskie programy informacyjne, publicystyczne, filmy i seriale. Nawet jednak przy założeniu, że student czerpie z wypowiedzi wykształconych rodzimych użytkowników ruszczyzny, konieczne jest stosowanie zasady ograniczonego zaufania. W wypowiedziach ustnych zdarzają się przejęzyczenia, nieświadome oraz świadome odstępstwa od normy. Te ostatnie są wykorzystywane w celach parodystycznych, humorystycznych oraz jako element charakterystyki postaci (w filmach, przedstawieniach itp.), dlatego też student z czasem powinien nabyć umiejętność rozpoznawania ich, co uznałbym za składową szeroko rozumianych kompetencji językowych. W przypadku wypowiedzi przygotowanych (niespontanicznych), obecnych na przykład w filmach, przypadkowe błędy pojawiają się raczej rzadko, a jeśli już występują, to są najczęściej wynikiem świadomego zabiegu. Natomiast w materiałach zawierających wypowiedzi spontaniczne (audycje informacyjne, wszelkie relacje bezpośrednie, programy na żywo) - prawdopodobieństwo przejęzyczeń, przypadkowych błędów oraz wypowiedzi z elementami niestandardowymi jest znacznie większe. Stąd też z większym zaufaniem student powinien traktować wypowiedzi przygotowane, zwłaszcza znanych prezenterów telewizyjnych i aktorów, a także tych polityków i innych osób publicznych, które znane są z dbałości o poprawność językową i zdolności oratorskich. Jednak i w tym przypadku możliwe jest (raczej sporadyczne) używanie niepoprawnych form akcentuacyjnych, o czym świadczy m.in. niezwykle ciekawa monografia poświęcona najczęściej popełnianym w rosyj- 
skich środkach masowego przekazu błędom (w tym akcentuacyjnym) przez znane, wymieniane z nazwiska, osobowości: Не говори шершавым языюком (О нарушениях норм литературной речи в электронных и печатных СМИ) (М.В. Горбаневский/ Ю. Н. Караулов/ В. М. Шаклеин 1999). Pamiętajmy, że student powinien wyrobić sobie nawyk samodzielnego sprawdzania form wzbudzających wątpliwości w najwłaściwszym do tego celu źródle, jakim jest jeden z wcześniej wymienionych słowników ortofonicznych języka rosyjskiego.

Powstaje jednak pytanie, jak często sięgać po słownik akcentuacyjny. Ciągłe kontrolowanie, a więc sprawdzanie każdej formy, jest zajęciem mało atrakcyjnym i mało produktywnym. Wydaje się, że przy zastosowaniu starannego doboru źródeł prawdopodobieństwo natrafienia na niepoprawną formę nie jest wielkie. Poza tym ewentualne odstępstwa od normy w mowie wykształconych natywnych użytkowników ruszczyzny noszą zazwyczaj charakter systemowy, odzwierciedlają tendencje rozwojowe języka i obejmują stosunkowo niewielką grupę stale powtarzających się form. Ewentualne zapamiętanie takiej wątpliwej (nie uznanej za normatywną (jeszcze?) przez normalizatorów formę) jest znacznie mniej niebezpieczne z punktu widzenia kompetencji językowej od używania form błędnych, spotykanych jedynie w mowie nienatywnych użytkowników języka rosyjskiego. Poruszając tę kwestię, warto odwołać się do celnego sformułowania autorstwa W.P. Bierkowa: „Языковой коллектив очень хорошо чувствует разницу между «своим» неверным (например, просторечным) словесным ударением и «чужим» неверным. Варианты начать, положить, понялла и поняла - «свои», а произношение деятель - «чужое» (шуточное употребление здесь не обсуждается)” (В.П. Берков 2011: 43).

\section{Wnioski}

Fundamentalne, wymienione już w tekście, prace w zakresie akcentologii rosyjskiej, w których sformułowano paradygmaty i reguły akcentuacyjne oraz liczne podręczniki do nauki akcentu rosyjskiego (M. Olechnowicza, D. Dziewanowskiej, M.N. Szutowej i inne) stanowią punkt wyjścia do efektywnego nauczania studentów rusycystyki. Natomiast utrwalanie nabytych umiejętności oraz efektywne poszerzanie aktywnego zasobu leksykalno-frazematycznego z poprawnym umiejscowieniem przycisku w różnych formach gramatycznych może być dokonywane w ramach godzin audytoryjnych oraz, co jeszcze istotniejsze, samodzielnie przez uczącego się na bazie nagrań audiowizualnych w postaci rosyjskich programów informacyjnych, seriali i filmów przy świadomym zastosowaniu wymienionych $\mathrm{w}$ artykule schematów działania. Dane schematy pozwalają na wyjście poza siłą rzeczy ograniczony materiał leksykalny obecny na zajęciach praktycznych z języka kierunkowego i stałe samodoskonalenie się, nawet w czasie nie przewidzianym specjalnie na przyswajanie akcentu (rozmowa z Rosjaninem, oglądanie filmu w celach rozrywkowych). Ponadto zwiększają się faktyczne możliwości zapamiętywania i utrwalania licznych reguł i prawidłowości rosyjskiej akcentuacji, które w oderwaniu od żywego materiału językowego, nie są łatwe do opanowania pamięciowego. 


\section{Skróty słowników}

SA Орфоэпический словарь русского языка: Произношение, ударение, грамматические формы, Р.И. Аванесов (red.), Москва 1989, 5-е изд., испр. и доп.

SAg Агеенко Ф.Л., (2001), Словарь собственных имён русского языка, Москва.

SIw Иванова, Т.Ф. (2004), Новый орфоэпический словарь русского языка: Произночение, ударение, грамматические формы. Москва.

SЈе Еськова, Н.А./ С.Н. Борунова / В.Л. Воронцова (2014), Орфоэпический словарь русского языка: произночение, ударение, грамматические формь (10-е изд., испр. и доп.). Москва.

SK Каленчук М.Л./ Л.Л. Касаткин/ Р.Ф. Касаткина (2012), Большой орфоэпический словарь русского языка: литературное произночение и ударение начала XXI века: норма и её варианты. Москва.

SR Резниченко, И.Л. (2003), Орфоэпический словарь русского языка: Произночение. Ударение. Москва.

SZ Зарва, М.В. (2001), Русское словесное ударение: Словарь. Москва.

\section{Bibliografia}

Dziewanowska, D. (2005), Aspektowo-kompleksowe nauczanie akcentuacji na studiach rusycystycznych. Kraków.

Dziewanowska, D. (2000a), Akcent w języku rosyjskim : ćwiczenia praktyczne. Cz. 1, Czasownik. Warszawa.

Dziewanowska, D. (2000b), Akcent w języku rosyjskim : ćwiczenia praktyczne. Cz. 2, Rzeczownik. Warszawa.

Dziewanowska, D. (2000c), Akcent w języku rosyjskim : ćwiczenia praktyczne. Cz. 3, Przymiotnik, liczebnik, zaimek, imiestów. Warszawa.

Gałecki, W. (1965), Metodyka nauczania języka rosyjskiego w szkole podstawowej. Warszawa.

Henzel, J. (1978), Nauczanie języka rosyjskiego metoda reproduktywno-kreatywna. Kraków.

Olechnowicz, M. (1974a), Rosyjski system akcentuacyjny. Łodź.

Olechnowicz, M. (1974b), Teoretyczne zasady dystrybucji rosyjskiego akcentu wyrazowego. Łódź.

Olechnowicz, M. (1974c), Упражнения по интонации и акцентуации русского языка / Ćwiczenia z intonacji i akcentuacji rosyjskiej. Warszawa.

Olechnowicz, M. (1976), Методика обучения русскому ударению в польской школе. Łódź.

Olechnowicz, M. (1977), Akcent rosyjski. Wrocław.

Аванесов, Р.И. (1955), Ударение в современном русском литературном языке. Москва.

Аванесов, Р.И. (1968), Русское литературное произношение: Учебное пособие для студентов педагогических институтов (4-е изд., перераб. и доп). Москва.

Берков, В.П. (2011), Работы по языкознанию. Б.С. Жаров/ И.М. Михайлова/ 
А.В. Беркова/ С.Н. Беркова (red.). Санкт-Петербург.

Берков, В.П. (2005), Русские имена, отчества и фамилии. Правила употребления. Москва.

Богданович, Г.Ю./ Э.М. Сапожникова (2000), Орфография по правилам. Структурированный учебный словарь для студентов, абитуриентов и учашихся средних школ. Симферополь.

Воронцова, В.Л. (1979), Русское литературное ударение ХVIII-XX в. Формь словоизменения. Москва.

Горбаневский М. В./ Ю.Н. Караулов/ В.М. Шаклеин (1999), НЕ ГОВОРИ ШЕРШАВЫМ ЯЗЫКОМ (О нарушениях норм литературной речи в электронных и печатных СМИ). (URL http://gramota.ru/biblio/research/rubric_370). [Pobrano 10.03.2016].

Горбачевич, К.С. (1978), Нормы современного русского литературного языка. Пособие для учителей. Москва.

Зализняк, А.А. (1967), Русское именное словоизменение. Москва.

Зализняк, А.А. (1985), От праславянской акцентуации к русской. Москва.

Зализняк, А.А. (2009), Грамматический словарь русского языка. Словоизменение: (Изд. 6-е, стер). Москва.

Каленчук М.Л./ Л.Л. Касаткин/ Р.Ф. Касаткина (2012), Орфоэпические правила, (w:) Большой орфоэпический словарь русского языка. Литературное произношение и ударение начала XXI века: норма и её варианты. Москва, 938-1000.

Колесов, В.В. (1972), История русского ударения: Именная акцентуация в древнерусском языке. Ленинград.

Лебедева Ю.Г. (1986), Звуки, ударение, интонация. Москва.

Пчелов Е.В. / В.Т. Чумаков (2000), Два века русской буквы Ё: История и словарь. Москва.

Редькин, В.А. (1971), Акиентология современного русского литературного языка. Москва.

Резниченко, И.Л. (2015), Словарь ударений русского языка: около 10000 слов, все трудные случаи, все типь ударений, способы запоминания. Москва.

Суперанская, А.В. (1968), Ударение в собственных именах в современном русском языке. Москва.

Суперанская, А.В. (2011), Ударение в собственных именах в современном русском языке. Изд. 2-е, испр. Москва.

Федянина, Н.А. (1976), Ударение в современном русском языке: [Учеб. пособие для студентов-иностранцев, обучающихся на филол. фак. вузов СССР]. Москва.

Хазагеров, Т.Г. (1973), Развитие типов ударения в системе русского именного склонения. Москва.

Шутова, М.Н. (2013), Пособие по обучению русскому ударению для изучающих русский язык как иностранный. Москва. 